\title{
A Modification of Palm Waste Lignocellulosic Materials into Biographite Using Iron and Nickel Catalyst
}

\author{
Noor Hafidzah Jabarullah ${ }^{1, *}$, Afiqah Samsul Kamal ${ }^{2}$ and Rapidah Othman ${ }^{2}$ (D) \\ 1 Malaysian Institute of Aviation Technology, Universiti Kuala Lumpur, Sepang 43900, Malaysia \\ 2 Chemical Engineering Section, Malaysian Institute of Chemical and Bioengineering, Universiti Kuala \\ Lumpur, Melaka 78000, Malaysia; afiqah.samsul30@s.unikl.edu.my (A.S.K.); rapidah@unikl.edu.my (R.O.) \\ * Correspondence: nhafidzah@unikl.edu.my
}

check for updates

Citation: Jabarullah, N.H.; Kamal, A.S.; Othman, R. A Modification of Palm Waste Lignocellulosic Materials into Biographite Using Iron and Nickel Catalyst. Processes 2021, 9 , 1079. https://doi.org/10.3390/ pr9061079

Academic Editor: Lucian-Ionel Cioca

Received: 19 May 2021

Accepted: 16 June 2021

Published: 21 June 2021

Publisher's Note: MDPI stays neutral with regard to jurisdictional claims in published maps and institutional affiliations.

Copyright: (c) 2021 by the authors. Licensee MDPI, Basel, Switzerland. This article is an open access article distributed under the terms and conditions of the Creative Commons Attribution (CC BY) license (https:/ / creativecommons.org/licenses/by/ $4.0 /)$.
Abstract: This paper presents an alternative way to maximize the utilization of palm waste by implementing a green approach to modify lignocellulosic materials into a highly crystalline biographite. A bio-graphite structure was successfully synthesized by converting lignocellulosic materials via a simple method using palm kernel shell (PKS) as a carbon precursor. This involved the direct impregnation of a catalyst into raw material followed by a thermal treatment. The structural transformation of the carbon was observed to be significantly altered by employing different types of catalysts and varying thermal treatment temperatures. Both XRD and Raman spectroscopy confirmed that the microstructural alteration occurred in the carbon structure of the sample prepared at 800 and $1000{ }^{\circ} \mathrm{C}$ using iron, nickel or the hybrid of iron-nickel catalysts. The XRD pattern revealed a high degree of graphitization for the sample prepared at $1000^{\circ} \mathrm{C}$, and it was evident that iron was the most active graphitization catalyst. The presence of an intensified peak was observed at $2 \theta=26.5^{\circ}$, reflecting the formation of a highly ordered graphitic structure as a result of the interaction between the iron catalyst and the thermal treatment process at $1000{ }^{\circ} \mathrm{C}$. The XRD observation was further supported by the Raman spectrum in which PKS-Fe1000 showed a lower defect structure associated with the presence of a significant amount of graphitic structure, as a low value of $\left(\mathrm{I}_{\mathrm{d}} / \mathrm{I}_{\mathrm{g}}\right)$ ratio was reported. An HRTEM image showed a well-defined lattice fringe seen on the structure for PKS-Fe1000; meanwhile, a disordered microstructure was observed for the control sample, indicating that successful structural modification was achieved with the aid of the catalyst. Further analysis from BET found that the PKS-Fe1000 developed a surface area of $202.932 \mathrm{~m} 2 / \mathrm{g}$ with a pore volume of $0.208 \mathrm{~cm} 3 / \mathrm{g}$. An overall successful modification from palm waste into graphitic material was achieved. Thus, this study will help those involved in waste management to evaluate the possibility of a sustainable process for the generation of graphite material from palm waste. It can be concluded that palm waste is a potential source of production for graphite material through the adoption of the proposed waste management process.

Keywords: palm kernel shell; graphite; catalytic graphitization; biomass waste

\section{Introduction}

Malaysia and Indonesia are the largest producers of palm oil, contributing more than $80 \%$ of the global annual yield [1]. Oil palm is among the best known and most extensively cultivated plant families in Malaysia, as compared to another commodities [2]. Various products are derived from oil palm, such as in the food, cosmetic, animal feed and pharmaceutical industries [3]. However, increases in the demand for oil palm products leads to an increase in the waste produced annually [4]. A huge amount of biomass wastes produced from the palm oil industry comprises palm kernel shell (PKS), empty fruit bunch (EFB) and palm mesocarp fibre (PMF) [1,5].

Current European Union waste management directives promote the prevention of waste and the application of waste management hierarchy [6]. Sustainable waste management is an essential step to overcoming the waste generation issue [7-9]. The hierarchy 
of waste management includes prevention, reuse, recycling, recovery and disposal [10]. The utilization of waste plays an important role in the transition to a circular economy as waste is reused to produce other valuable biomaterials that indirectly enhance economic growth $[2,11,12]$. This is related to the waste to wealth concept.

Lignocellulosic biomass waste is an ideal source of cellulose-based natural fibre and a good source of biomaterial [2]. It has received a large amount of attention due to its potential to be utilized in a wide range of applications, such as the development of biocomposites, power generation, paper production, biofertilizers, super-capacitors and water purification $[2,5,13,14]$. Lignocellulosic biomass is a natural, non-toxic, abundant, sustainable and renewable material, making it a good candidate for a wide range of applications [15-17].

Lignocellulosic biomass is naturally porous with a hierarchical structure and large surface area [18]. The porous structure is beneficial as it provides an ion transport pathway; it can also be easily combined with other materials to form a hybrid material that exhibits enhanced material electrochemical properties [19]. Lignocellulosic is also a carbonrich material with heteroatom-doping characteristics, making it attractive for use as a substitute of conventional carbon material [18]. Biomass-derived carbon materials have given rise to extensive interest due to their biodiversity, unique microstructure and good conductivity [20-22].

Today, research has shifted toward abundantly available and low-cost materials, such as lignocellulosic waste [23]. Initiatives of producing carbon material from biomass waste will subsequently help in reducing environmental issues and maximizing utilization [24]. However, challenges occur as raw biomass is made up of many different macromolecules, small molecules and inorganic component, such as cellulose, hemicellulose, lignin and tannins [25]. Different components exhibit different thermal decomposition and chemical properties, which make the synthesis process difficult as compared to purified derivatives, such as cellulose [25].

Palm waste, such as palm kernel shell (PKS) waste, is currently being utilized as biofuel for steam generation as it has a higher heating rate than other palm wastes. Additionally, its small size, ease of handling and limited biological activity due to its lower moisture content make PKS attractive for use in the production of activated carbon, polymer biocomposite and as concrete pavement [26]. One strategy to fully utilize this biomass waste is using it as a main feedstock for the production of carbon material. Previously, many researchers' works have investigated different raw materials, such as sawdust, saccharides, corn stalk, green tea waste, coconut coir and coconut stalk waste as raw materials for carbon material production.

Carbon materials have raised great interest in a wide range of applications. This interest has resulted from its diverse beneficial properties. Properties such as high chemical stability, good electrical conductivity and high thermal stability have increased interest in many areas. Carbon materials have been widely used in filtration, separation technology, electrodes and energy devices. There are several types of carbon material that are prominent among researchers, including carbon nanotubes, graphene and graphene oxide.

Among the carbon materials that are widely investigated is graphite. Graphite is one form of carbon allotrope that has attracted tremendous interest due to its mechanical, electrical and thermal properties [27,28]. The metallic (high electrical and thermal conductivities) and non-metallic properties (high thermal resistance, inertness and lubricity) of graphite make it an essential material for refractories, automobiles, lithium-ion batteries, fuel cells, solar cells and graphene production [29-31].

The common method in graphite manufacturing is known as the Ancheson process [30]. The process involved the thermal heating of amorphous carbon up to $3000^{\circ} \mathrm{C}$. The energy and time consumption is tremendously high, as it involves about a 2 week processing period, leading to high production costs [30]. In a later development, graphite was also prepared using other methods, such as arc discharge, laser ablation, chemical vapour deposition (CVD) and solvothermal synthesis [32,33]. However, these methods 
require extreme condition, such as a high temperature, high-energy consumption and special and expensive equipment $[33,34]$. In some cases, it produces graphite with a low specific surface area, which is not favourable [34].

Catalytic graphitization, on the other hand, is a heat treatment process involving a metal catalyst to enhance the process [33]. Unlike the other methods mentioned above, catalytic graphitization involves moderate process conditions with a relatively low temperature and energy consumption. It utilizes solid feedstock, which is an attractive option due to its easy handling and transport. Therefore, a feasible method, such as catalytic graphitization using lignocellulosic materials as a carbon precursor, have become an attractive option $[32,35,36]$.

Catalytic graphitization is the process of transforming amorphous carbon into a wellordered graphitic structure by a heat treatment in the presence of metals or minerals. Preovious researchers have reported on the utilization of transition metals such as $\mathrm{Fe}, \mathrm{Co}$, $\mathrm{Ni}, \mathrm{Mg}$ or metalloid elements, during graphitization processes using a variety of carbon precursors, ranging from coal wastes to biomass materials [25,37-41]. Among them, $\mathrm{Fe}, \mathrm{Ni}$ and Co have been found to be effective catalysts in graphite production [41]. Among the most widely investigated catalyst is iron, as it was reported as the most effective catalyst in a number of research works $[25,32,42-44]$. Iron is an attractive metal due to its toxicity, magnetization and cost effectiveness [44]. Previous researchers have studied the effect of different nitrate salts of copper, nickel, cobalt and iron on graphitization and concluded that the iron nanoparticle was the most active catalyst [43]. Qiangu et al. (2018) also reported a comparable finding that iron was the most active catalyst [45].

Based on the decision to take advantage of lignocellulosic waste and focusing on transforming toward sustainable economy, it is vital to study the optimization of production conditions $[2,5,6]$. Although catalytic graphitization using palm kernel shell has been reported previously $[46,47]$, these studies incorporated PKS with supporting materials, such as paraffin and petroleum coke, to form an activated carbon. It is very important to note that the structures of activated carbon and graphite are significantly different. The latter has a higher electrical and thermal conductivity with a lower surface area than the former. In our study, we successfully transformed the amorphous carbon structure of PKS into highly graphitic carbon similar to natural graphite using a heat treatment at 800 and $1000^{\circ} \mathrm{C}$ with the presence of $\mathrm{Fe}, \mathrm{Ni}$ and the hybrid Fe-Ni catalyst. We designate the highly graphitic structure of PKS as biographite.

\section{Materials and Methods}

\subsection{Sample Preparation}

Palm kernel shell (PKS) was collected from Bell KSL Kilang Sawit Linggi, Negeri Sembilan. The raw materials were firstly air-dried for $24 \mathrm{~h}$ to remove excess moisture before being cut and chopped into smaller sizes. Approximately $150 \mathrm{~g}$ of the material was washed with hot deionized water at $80{ }^{\circ} \mathrm{C}$ to remove impurities. Later, the material was oven dried at $70{ }^{\circ} \mathrm{C}$ for $24 \mathrm{~h}$. Then, the washed material was ground and sieved to achieve a uniform size of $206 \mu \mathrm{m}$. The raw material was divided into three parts of $50 \mathrm{~g}$ each.

\subsection{Catalyst Preparation}

An amount of $1 \mathrm{M}$ aqueous solution of iron (III) nitrate nonahydrate was prepared by mixing $40.399 \mathrm{~g}(10 \mathrm{wt} . \%)$ iron (III) nitrate nonahydrate in $100 \mathrm{~mL}$ deionized water at an ambient temperature of $25^{\circ} \mathrm{C}$. Nickel (II) nitrate hexahydrate solution was prepared by adding $29.079 \mathrm{~g}(10 \mathrm{wt} . \%)$ to $100 \mathrm{~mL}$ deionized water at an ambient temperature of $25{ }^{\circ} \mathrm{C}$. Meanwhile, the hybrid ferum and nickel catalyst comprised a mixture of 1:1 part $40.399 \mathrm{~g}$ (10 wt.\%) iron (III) nitrate nonahydrate and nickel (II) nitrate hexahydrate $29.079 \mathrm{~g}$ (10 wt.\%) with $100 \mathrm{~mL}$ deionized water at an ambient temperature of $25^{\circ} \mathrm{C}$. 


\subsection{Bio-Graphite Preparation}

An amount of $50 \mathrm{~g}$ of PKS sample was immersed in $100 \mathrm{~mL}$ of $1.0 \mathrm{M}$ aqueous solutions of iron (II) nitrate hexahydrate ( $29.079 \mathrm{~g})$ and stirred for $48 \mathrm{~h}$. The samples were then filtered and dried at $80^{\circ} \mathrm{C}$. The sample was divided into two parts for graphitization at 1000 and $800^{\circ} \mathrm{C}$, respectively. The sample was placed in a quartz holder and inserted into a Carbolite 1800C Tube Furnace/Model CTF 18/300. The samples underwent heat treatment with a heating rate of $5{ }^{\circ} \mathrm{C} / \mathrm{min}$ in a nitrogen atmosphere. After the graphitization, the residual metal catalyst was removed by stirring in $1.0 \mathrm{M} \mathrm{HCl}$ for $24 \mathrm{~h}$ followed by washing it using deionized water. Then, it was dried in an oven at a temperature of $80^{\circ} \mathrm{C}$ overnight. The samples were denoted as PKS Fe-1000 and PKS Fe-800. The steps were repeated using an aqueous solution of nickel (II) nitrate hexahydrate and a hybrid of iron (III) nitrate nonahydrate and nickel (II) nitrate hexahydrate. Samples were denoted as PKS Ni-800, PKS Ni-1000, PKS Fe Ni-800 and PKS Fe Ni-1000. A reference control sample was also prepared by directly inserted PKS raw material into a tube furnace at $1000{ }^{\circ} \mathrm{C}$ without the addition of any catalyst, and the sample was denoted as PKS control-1000.

\subsection{Characterization}

X-ray diffraction (XRD) patterns were obtained from $2 \theta=2$ to $90^{\circ}$ in a PAN analytic $X^{\prime}$ Pert Pro diffractometer using $\mathrm{Cu} \mathrm{K} \alpha$ radiation $(\lambda=1.5406 \AA, 45 \mathrm{kV}, 40 \mathrm{~mA})$, used for the identification of minerals. Raman spectra were recorded using the Renishaw MicroRaman system 2000 with He-Ne laser excitation $\lambda=632$. An FEI Tecnai G2 20 S-twin transmission electron microscope ((HR)TEM, FEI), operated at $200 \mathrm{kV}$ and equipped with a filed-emission gun, supplied information about the structure of carbon materials. The surface area and pore size measurements were carried out by $\mathrm{N}_{2}$ adsorption/desorption isotherms using Micromeritics2360, ASAP2020.

\section{Results and Discussion}

\subsection{Crystallographic Properties}

The XRD patterns in the wide angle region, $2-90^{\circ}$, permitted an evaluation of the graphitic nature of the synthesized biographite. The analysis was carried out to characterize the crystallinity of the composites [48]. PKS samples were introduced into $\mathrm{Fe}$, $\mathrm{Ni}$ and $\mathrm{FeNi}$ catalysts, respectively, and underwent heat treatment at a temperature of 800 and $1000{ }^{\circ} \mathrm{C}$. The XRD patterns for all samples prepared under different conditions are shown in Figure 1. For the optimal synthesis condition of lignocellulosic waste modification, two main factors, including heat treatment temperature and type of catalyst, were among the important aspects. The effect of the temperature and catalyst were determined by XRD patterns.

Figure 1 shows the XRD patterns for each sample at 800 and $1000{ }^{\circ} \mathrm{C}$ with $10 \mathrm{wt} . \%$ catalyst loading, and the control sample. Most of the samples exhibited the presence of a sharp peak located at $2 \theta \sim 26^{\circ}$, corresponding to the (002) plane of graphite [40,49-51]. This confirms the transformation of PKS waste to a bio-graphite structure. The samples prepared using iron, nickel and a hybrid iron-nickel catalyst also exhibited diffraction peaks at $2 \theta \sim 44^{\circ}, 50^{\circ}$ and $59.98^{\circ}$, corresponding to (101), (102) and (103) diffractions of graphite frameworks, respectively.

It can be clearly observed that the sample prepared at a higher temperature showed strong reflection at $2 \theta \sim 26^{\circ}$, which is associated with a strong degree of graphitization, regardless of the type of catalyst used. The peak was significantly intensified with an increase in the graphitization temperature. These results are similar to those reported by previous research works $[37,40,52-54]$. The observations were also comparable to the work carried out by Yang et al. (2019), which utilized sucrose as a carbon precursor and successfully produced a well-ordered graphite structure at higher temperatures [55]. 


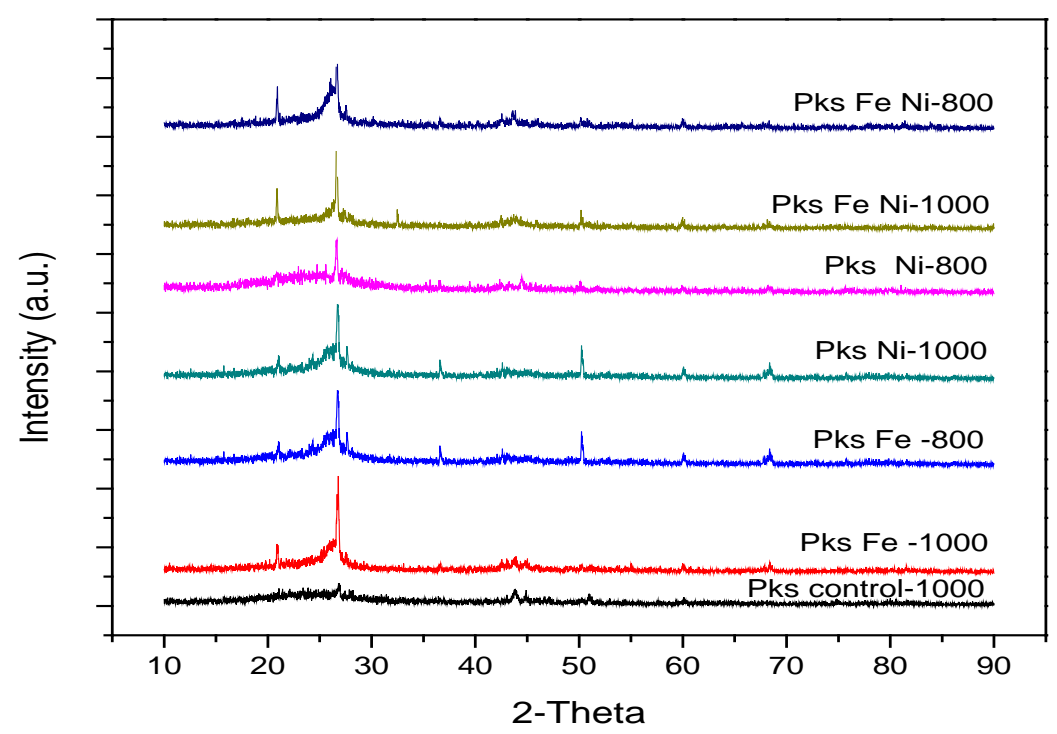

Figure 1. XRD pattern for PKS sample prepared with different temperatures and catalysts.

To further discuss the effect of catalyst selection, XRD profiles for PKS samples prepared with different catalysts at $1000{ }^{\circ} \mathrm{C}$ were compared. A significant sharp and narrow diffraction peak obtained for the sample prepared using an iron catalyst at $2 \theta \sim 26^{\circ}$ indicates that a high degree of crystallinity of graphitized carbon can be obtained by using iron as compared to nickel and a hybrid iron-nickel catalyst. The PKS control-1000 sample, on the other hand, showed almost no visible graphite peak. The PKS control sample was prepared by undergoing heat treatment at $1000{ }^{\circ} \mathrm{C}$ without any catalyst. This proved that PKS waste with the absence of a catalyst is not graphitizable at $1000^{\circ} \mathrm{C}$.

From the XRD pattern, it can be deduced that the degree of graphitization increased with the graphitization temperature and the application of an iron catalyst. Therefore, the value of $\mathrm{d}_{002}$ spacing was calculated according to Bragg's equation, as shown in Table 1 [56]. The value of $\mathrm{d}_{002}$ spacing was observed in the range between 0.3325 and $0.3351 \mathrm{~nm}$, close to the value of graphite $(0.3354 \mathrm{~nm})$ and less than $0.344 \mathrm{~nm}$ for the disordered carbon material. Of all the catalysts, PKS Fe-1000 $(0.3351 \mathrm{~nm})$ was the nearest to $0.3354 \mathrm{~nm}$, corresponding to the ideal graphite and suggesting that an ordered carbon framework was achieved [57]. This suggests that the structure of PKS Fe-1000 was altered and transformed into graphite. Numerous previous studies have modified biomass into graphite, and the d-spacing data were mostly close to graphite. Xiangyang et al. (2016) used wheat stalk as a carbon precursor and reported d-spacing of $0.3362 \mathrm{~nm}$, and Jujiao et al. (2016) reported $0.34 \mathrm{~nm} \mathrm{~d}$-spacing using chitosan [58]. Other findings show $\mathrm{d}$-spacing between 0.337 and 0.346 using various raw materials $[24,28,44,55,59]$.

Table 1. d-spacing data of all graphitic carbon samples.

\begin{tabular}{lll}
\hline \multicolumn{1}{c}{ Sample } & $\mathbf{d}_{\mathbf{0 0 2}} \mathbf{n m}$ \\
\hline PKS Fe-800 & 0.3348 & \\
PKS Fe-1000 & 0.3351 & \\
PKS Ni-800 & 0.3325 & \\
PKS Ni-1000 & 0.3327 & \\
PKS FeNi-800 & 0.3343 & \\
PKS FeNi-1000 & 0.3344 & \\
PKS control-1000 & 0.3391 & \\
Graphite commercial & 0.3354 & \\
\hline
\end{tabular}

The structural parameters of this sample were further deduced from the XRD profile via peak fitting. Crystallite sizes along the c-axis, Lc and a-axis La were deduced by means of Scherrer's equation applied to the (002) and (101) diffraction peaks [60]. The $\mathrm{d}_{002}$ values 
for the control sample were larger, $0.3391 \mathrm{~nm}$, suggesting that it still has a turbostatic carbon structure.

The crystallographic structure modification of the PKS Fe-1000 sample was further detected by Raman spectra. Raman spectra can identify the presence of graphite or a disordered amorphous structure in the sample [45]. For the graphitic carbon material, two strong resonance peaks at 1580 and $1350 \mathrm{~cm}^{-1}$ were observed. A peak at $1580 \mathrm{~cm}^{-1}$ represents the vibration in an ideal graphite lattice $(G)$ band $[30,52,60]$. Meanwhile, the $D$ $\left(1350 \mathrm{~cm}^{-1}\right)$ band appeared with the increase in structural defects due to imperfections or loss of hexagonal symmetry $[45,61]$. The peak intensity ratios of the $G$ and D1 bands are indicators of the defect density of carbon material [52]. By means of Raman spectroscopy, it was possible to analyse the degree of structural organization of the graphitic carbon sample. The relative intensity ratio between the $\mathrm{D}$ and $\mathrm{G}$ bands $\left(\mathrm{I}_{\mathrm{d}} / \mathrm{I}_{\mathrm{g}}\right)$ and width at half maximum of the $G$ bands $\left(\Delta v_{G}\right)$ reflected the degree of graphitization. Low values of $I_{d} / I_{g}$ and $\Delta v_{G}$ parameters clearly indicate a high degree of graphitization [50]. Raman spectra forPKS Fe-1000 sample was compared with commercial graphite and the PKS control sample in Figure 2.

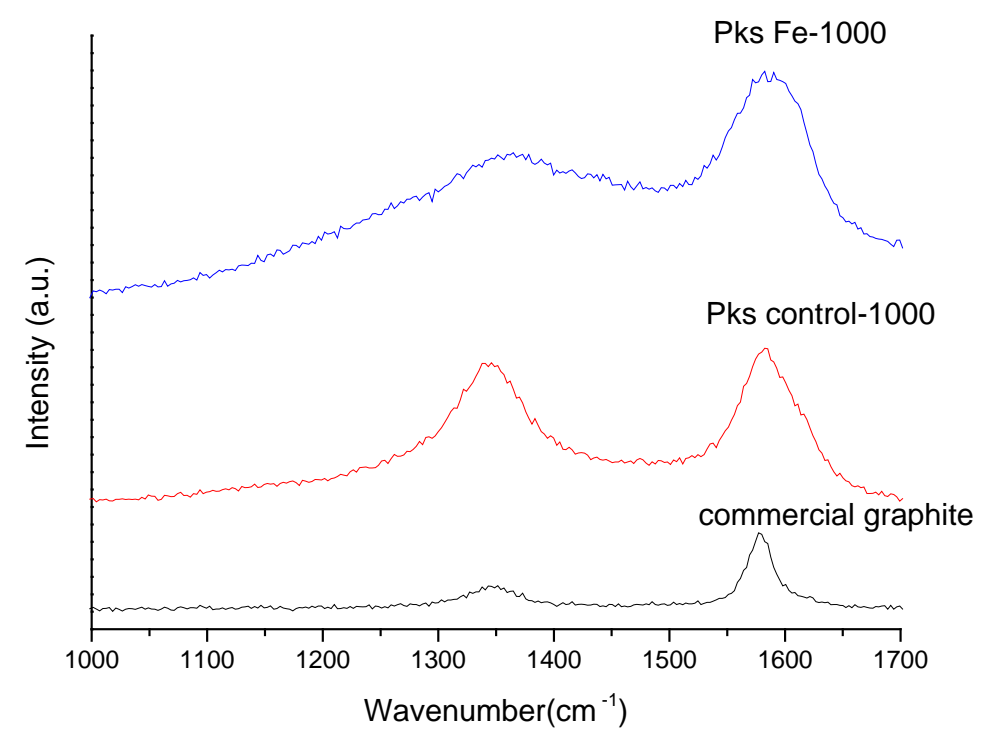

Figure 2. Raman spectra for Pks Fe-1000, PKS control and commercial graphite.

A higher $\mathrm{D} / \mathrm{G}$ peak intensity $\left(\mathrm{I}_{\mathrm{d}} / \mathrm{I}_{\mathrm{g}}\right)$ ratio reveals more structural defects in carbon material. As reported in Table 2, the $\mathrm{I}_{\mathrm{d}} / \mathrm{I}_{\mathrm{g}}$ values for PKS Fe-1000, commercial graphite and PKS control-1000 were $0.985,0.576$ and 1.632 , respectively. The $\mathrm{I}_{\mathrm{d}} / \mathrm{I}_{\mathrm{g}}$ values were similar, as reported by a previous researcher, ranging between 0.84 and $0.98 \mathrm{I}_{\mathrm{d}} / \mathrm{I}_{\mathrm{g}}$, with the utilization of lignin as a carbon source [20]. This further proved that thermal treatment at $1000{ }^{\circ} \mathrm{C}$ and an iron catalyst successfully induced a high degree of graphitization into the palm kernel shell (PKS) waste. The $\Delta v_{G}$ parameter and $I_{d} / I_{g}$ value showed a descending order value for the PKS control, PKS Fe-1000 and commercial graphite. Lower $\Delta v_{G}$ and $I_{d} / I_{g}$ values for PKS Fe-1000 showed that the successful alteration of the amorphous material was achieved. The Raman spectra data are comparable with the XRD findings. In addition, the control sample showed the highest Id/Ig value of 1.63 compared to PKS Fe-1000 and commercial graphite, suggesting the presence of a turbostratic structure. Both analyses from the XRD and Raman suggested that the graphitic structure of the PKS waste was remarkably produced with the aid of an iron catalyst and thermal treatment at $1000^{\circ} \mathrm{C}$. 
Table 2. Physical properties of synthesized graphitic carbon, commercial graphite and control sample.

\begin{tabular}{|c|c|c|c|c|c|c|c|c|}
\hline \multirow[t]{2}{*}{ Sample } & \multicolumn{3}{|c|}{$\begin{array}{c}\text { Structural } \\
\text { Characteristic }\end{array}$} & \multicolumn{2}{|c|}{ Raman Parameter } & \multicolumn{3}{|c|}{ Textural Properties } \\
\hline & $\begin{array}{l}\mathrm{d}_{002} \\
(\mathrm{~nm})\end{array}$ & $\begin{array}{c}\mathrm{Lc} \\
(\mathrm{nm})\end{array}$ & $\begin{array}{c}\mathrm{La} \\
(\mathrm{nm})\end{array}$ & $\mathbf{I}_{\mathrm{D}} / \mathbf{I}_{\mathrm{G}}$ & $\begin{array}{c}\Delta v_{\mathrm{G}} \\
\left(\mathrm{cm}^{-1}\right)\end{array}$ & $\underset{\left(\mathrm{m}^{2} \cdot \mathrm{g}^{-1}\right)}{\mathrm{S}_{\mathrm{BET}}}$ & $\begin{array}{l}\text { Pore Volume } \\
\left(\mathrm{cm}^{3} \cdot \mathrm{g}^{-1}\right)\end{array}$ & $\begin{array}{l}\text { Pore Size } \\
\text { (Å) }\end{array}$ \\
\hline \multirow{3}{*}{$\begin{array}{c}\text { Pks control } \\
\text { Commercial } \\
\text { graphite } \\
\text { Pks Fe-1000 }\end{array}$} & 0.3391 & 6.78 & 60.14 & 1.631 & 92.94 & 17.014 & 0.017 & 37.251 \\
\hline & 0.3354 & 43.47 & 37.25 & 0.576 & 33.66 & 0.3748 & 0.014 & 1592.1 \\
\hline & 0.3351 & 62.00 & 11.12 & 0.985 & 83.40 & 202.93 & 0.208 & 41.067 \\
\hline
\end{tabular}

\subsection{Morphology and Pore Structure}

To probe porosity, a nitrogen sorption-desorption isotherm was collected for PKS Fe-1000, PKS control and commercial graphite, as depicted in Figure 3. The BrunauerEmmett-Teller surface area (SABET) of the sample is $202.932 \mathrm{~m}^{2} / \mathrm{g}$. The value was found to be close to a study conducted by Thompson $\left(220 \mathrm{~m}^{2} / \mathrm{g}\right)$, as biomass waste was also utilized in his research [25]. The pore size of the sample is $4.107 \mathrm{~nm}$, which satisfied the range of pore size for mesoporous material $(2-50 \mathrm{~nm})$ and pore volume of $0.208 \mathrm{~cm}^{3} / \mathrm{g}$.

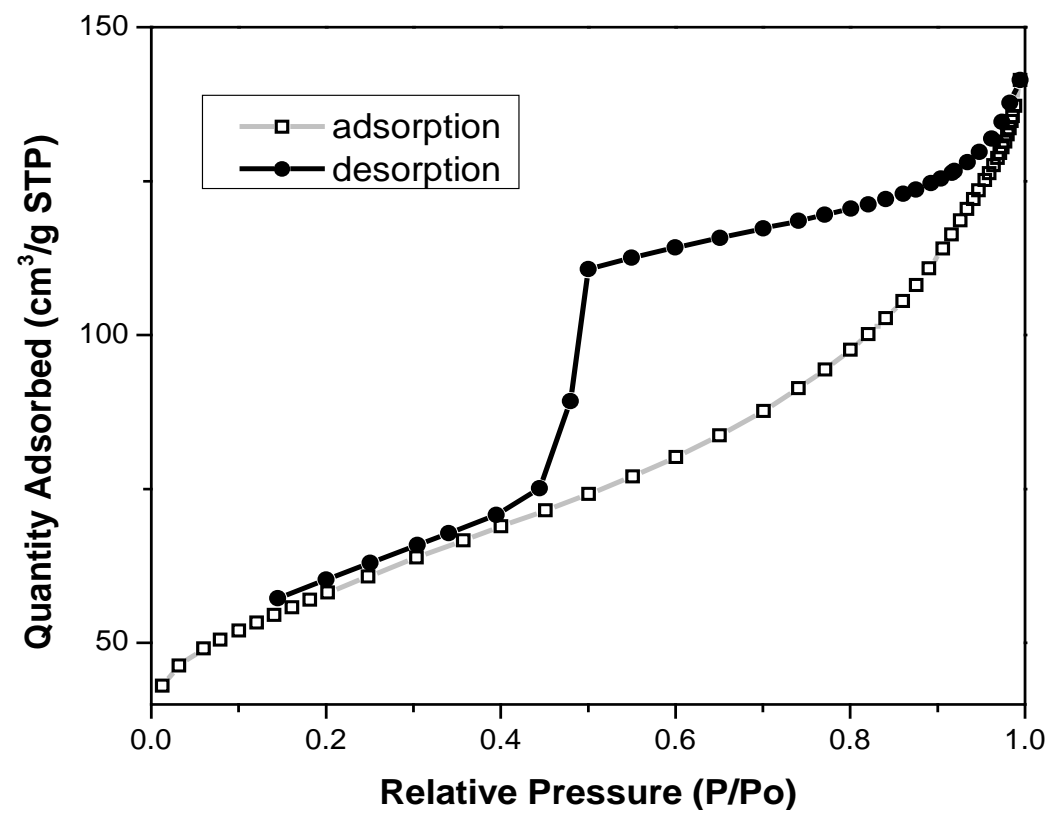

Figure 3. Nitrogen adsorption and desorption isotherm for PKS-Fe $1000{ }^{\circ} \mathrm{C}$.

The nitrogen sorption isotherm for PKS-Fe 1000 showed a type IV isotherm, with a hysteresis loop associated with capillary condensation that took place in mesopores. The type IV isotherm with a hysteresis loop was initiated at a relative pressure, $\mathrm{P} / \mathrm{P}_{\mathrm{o}}$, of approximately 0.17 and closing at 1.0. The hysteresis depicted the $\mathrm{H} 2$ class of hysteresis loops, which indicated a constriction associated with disordered carbon [62]. This provides a clear understanding of the types of pores that the graphitized carbon was evolved into as $\mathrm{H} 2$ hysteresis loops occurred when the pores were narrow mouth shapes (ink-bottles similar to pores), which resulted in a delay during desorption. This type of isotherm agrees with the data reported by Thompson et al. (2015), indicating the typical biomass responsible for mesopore structures [25].

Further insight into the detailed microstructures of the samples was elucidated with high-resolution transmission electron microscope (HRTEM) image analysis. Figure 4a shows an image of the PKS Fe-1000 sample; a visible set of core lattice fringes arising from graphitic carbon was observed $[28,63]$. This demonstrates a high degree of crystallinity in the PKS Fe-1000. On the other hand, the PKS control samples exhibited disordered microstructures typical of amorphous carbon, as shown in Figure $4 \mathrm{~b}$. Figure $4 \mathrm{c}$ shows 
the distinct lattice distance of graphite (002) with d-spacing of $0.33 \mathrm{~nm}$, which implied the presence of a well-graphitized structure that is beneficial for electron transport [63]. The estimated d-spacing from HRTEM is in good agreement with the XRD data. In summary, HRTEM analysis confirmed the successful modification of lignocellulosic waste into graphite.

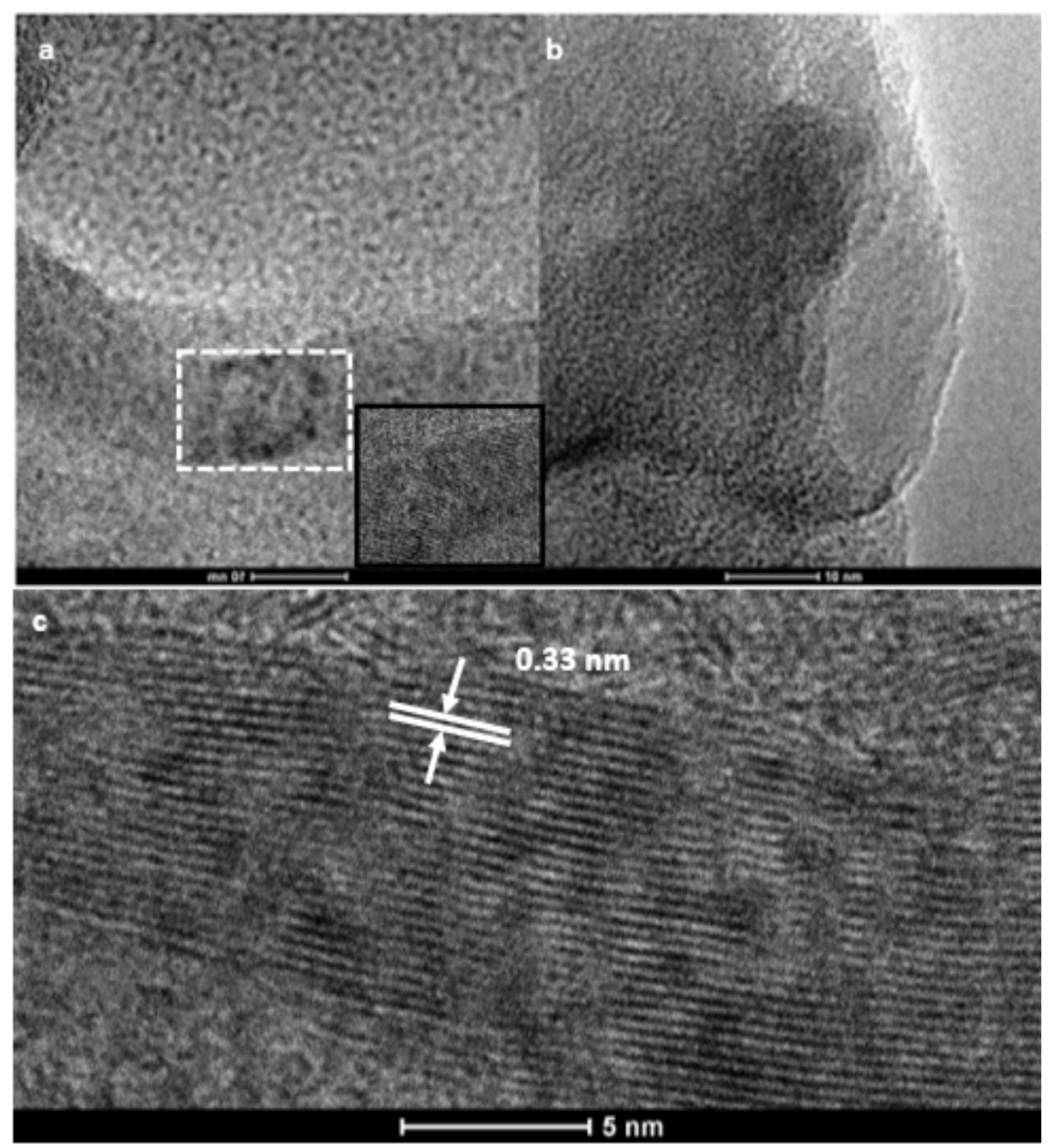

Figure 4. HRTEM image: (a) PKS Fe-1000 at 10 nm resolution; (b)PKS control-1000 at 10 nm resolution; (c) PKS Fe-1000 at $5 \mathrm{~nm}$ resolution.

The chemical composition of oil palm waste is a major factor that influences the degree of graphitization of carbon sources. Previous research work has suggested that selecting plant-based biomass with high lignin fraction, low cellulose fraction, low oxygen and high nitrogen content is important to ensure a high degree of graphitization [64].

PKS is made up of mainly cellulose, hemicellulose, Klason lignin, wax and ash. The composition in each component is different for each type of waste. A previous researcher conducted several tests to determine the composition of palm waste using a procedure recommended by the US National Renewable Energy Laboratory similar to ASTM E1758-01 [65]. It was found that PKS dry basis composition is made up of $14.7 \%$ cellulose, $16.4 \%$ hemicellulose, $53.6 \%$ Klason lignin, $2.3 \%$ wax, $2.3 \%$ ash and $10.7 \%$ (wt. $\%$, dry basis) other components [65]. Meanwhile, the ultimate analysis of PKS at $380{ }^{\circ} \mathrm{C}$ (wt.\%, daf at $380{ }^{\circ} \mathrm{C}$ ) shows that it is made up of $80.9 \%$ carbon, $4.8 \%$ hydrogen, $0.7 \%$ nitrogen, $13.8 \%$ oxygen and $0.1 \%$ sulphur [64]. The data show that PKS contains a high amount of lignin and carbon but a low amount of cellulose, comparable to the observations in other 
research work, suggesting the successful transformation of amorphous into a graphitic structure $[64,65]$.

\subsection{The Possible Mechanisms for Graphitization}

Several mechanisms have been proposed for the transformation of amorphous carbon structures into crystalline graphite with the addition of a catalyst. The addition of a metal catalyst has a significant remarkable impact on lowering the graphitization temperature [66]. Upon heat treatment, carbon atoms react with the catalyst to form several carbides, the decomposition of which results in the formation of graphite crystals. This process moves, assembles and disintegrates carbon atoms into graphite $[66,67]$. Dissolution-precipitation mechanisms have been proposed for the formation of graphite from amorphous carbon $[66,68]$. At a certain temperature, disordered carbon tends to diffuse and dissolve into metal or metal carbide and saturated carbon solubility reached under an equilibrium situation. With decreasing temperature, the metal saturated with the disordered carbon is supersaturated with carbon. Consequently, carbon precipitates in the form of graphite crystal because graphite is a highly ordered carbon with the lowest Gibbs free energy $[45,59]$.

\section{Conclusions}

In summary, a biographitic carbon material with high crystallinity and high $\mathrm{S}_{\mathrm{BET}}$ was successfully synthesized using palm kernel shell waste. Palm kernel shell is currently being utilized as a carbon precursor and ferum nitrate as a graphitization catalyst. The degree of graphitization can be regulated by changing the temperature and raw material, and also the type of catalyst. A higher heat treatment temperature of $1000{ }^{\circ} \mathrm{C}$ is responsible for a higher degree of graphitization. XRD data reported $2 \theta=26^{\circ}$ for all samples, but higher and sharper peaks were noticeable for the PKS prepared with an iron catalyst with a lower Id/Ig ratio, which indicated high crystallinity and low defects. The values of the $\mathrm{d}_{002}$ spacing of all the samples were between 0.3325 and 0.3351 , close to the value, 3.354 , of pure graphite and less than 3.44 for disordered carbon, proving that the production of graphite from lignocellulosic material is a promising alternative for reusing waste material, for a circular economy and zero-waste focal point.

Author Contributions: Conceptualization, N.H.J. and R.O.; methodology, A.S.K.; software, A.S.K.; validation, R.O. and N.H.J.; formal analysis, A.S.K.; investigation, A.S.K. and R.O.; resources, N.H.J.; data curation, A.S.K.; writing—original draft preparation, A.S.K.; writing-review and editing, R.O. and N.H.J.; supervision, R.O.; project administration, N.H.J.; funding acquisition, N.H.J. All authors have read and agreed to the published version of the manuscript.

Funding: The authors acknowledge the funding support from the FRGS Ministry of Higher Education grant (Ref: FRGS/1/2015/TK05/UNIKL/02/1).

Institutional Review Board Statement: Not applicable.

Informed Consent Statement: Not applicable.

Data Availability Statement: Data are available on request from the corresponding authors. The data are not publicly available due to the need for further research work.

Acknowledgments: The authors are grateful for the financial support from the FRGS grant and Bell KSL Sawit. Sdn. Bhd for supplying the raw material for this project.

Conflicts of Interest: The authors declare no conflict of interest. The funders had no role in the design of the study; in the collection, analyses, or interpretation of the data; in the writing of the manuscript; or in the decision to publish the results. 


\section{References}

1. Ma, Z.; Yang, Y.; Ma, Q.; Zhou, H.; Luo, X.; Liu, X.; Wang, S. Evolution of the chemical composition, functional group, pore structure and crystallographic structure of bio-char from palm kernel shell pyrolysis under different temperatures. J. Anal. Appl. Pyrolysis 2017, 127, 350-359. [CrossRef]

2. Dungani, R.; Aditiawati, P.; Aprilia, S.; Yuniarti, K.; Karliati, T.; Suwandhi, I.; Sumardi, I. Biomaterial from oil palm waste: Properties, characterization and applications. Palm Oil 2018. [CrossRef]

3. Book\&Claim. Green Palm Sustainability; Book\&Claim Ltd.: Hull, UK, 2016; Available online: https://greenpalm.org/about-palmoil/what-is-palm-oil/what-is-palm-oil-used-for (accessed on 1 October 2020).

4. Hamzah, N.; Tokimatsu, K.; Yoshikawa, K. Solid fuel from oil palm biomass residues and municipal solid waste by hydrothermal treatment for electrical power generation in Malaysia: A review. Sustainability 2019, 11, 1060. [CrossRef]

5. Dalton, S.; Mohamed, A.F.; Chikere, A.O. Status Evaluation of Palm Oil Waste Management Sustainability in Malaysia. OIDA Int. J. Sustain. Dev. 2017, 10, 41-48.

6. Pires, A.; Martinho, G. Waste hierarchy index for circular economy in waste management. Waste Manag. 2019, 95, 298-305. [CrossRef]

7. Hassan, M.A.; Abd-Aziz, S. Waste and Environmental Management in the Malaysian Palm Oil Industry; AOCS Press: Champaign, IL, USA, 2012; Volume 23. [CrossRef]

8. Choy, Y.K. Can palm oil waste be a solution to fossil fuel scarcity and environmental sustainability? A Malaysian case study provides the answer. Waste Manag. Environ. VIII 2016, 1, 97-108. [CrossRef]

9. Ślusarczyk, B.; Baryń, M.; Kot, S. Tire industry products as an alternative fuel. Polish J. Environ. Stud. 2016, 25, 1263-1270. [CrossRef]

10. Ungureanu, M.; Jozsef, J.; Brezoczki, V.M.; Monka, P.; Ungureanu, N.S. Research regarding the energy recovery from municipal solid waste in maramures county using incineration. Processes 2021, 9, 514. [CrossRef]

11. Bilan, Y.; Hussain, H.I.; Haseeb, M.; Kot, S. Sustainability and economic performance: Role of organizational learning and innovation. Eng. Econ. 2020, 31, 93-103. [CrossRef]

12. Kamal, S.; Jabarullah, N.H.; Othman, R. Catalytic graphitization of Oil Palm Frond using iron and silica. Mater. Today Proc. 2020, 31, 211-216. [CrossRef]

13. Chen, L.; Ji, T.; Mu, L.; Shi, Y.; Brisbin, L.; Guo, Z.; Khan, M.A.; David, P.; Zhu, J. Facile synthesis of mesoporous carbon nanocomposites from natural biomass for efficient dye adsorption and selective heavy metal removal. RSC Adv. 2016. [CrossRef]

14. Ramachandran, V.; Ismail, F.S.; Noor, M.J.M.M.; Akhir, F.N.M.; Othman, N.; Zakaria, Z.; Hara, H. Extraction and intensive conversion of lignocellulose from oil palm solid waste into lignin monomer by the combination of hydrothermal pretreatment and biological treatment. Bioresour. Technol. Rep. 2020, 11, 100456. [CrossRef]

15. Bień, J. Production and use of waste-derived fuels in Poland: Current status and perspectives. Prod. Eng. Arch. 2021, $27,36-41$. [CrossRef]

16. Sinaga, O.; Saudi, M.H.M.; Roespinoedji, D.; Jabarullah, N.H. Environmental impact of biomass energy consumption on sustainable development: Evidence from ARDL bound testing approach. Ekoloji 2019, 28, 443-452.

17. Jabarullah, N.H. The controversy of biofuel versus fossil fuel. Int. J. Adv. Appl. Sci. 2016, 3, 11-14.

18. Tang, W.; Zhang, Y.; Zhong, Y.; Shen, T.; Wang, X.; Xia, X.; Tu, J. Natural biomass-derived carbons for electrochemical energy storage. Mater. Res. Bull. 2017, 88, 234-241. [CrossRef]

19. Xiao, P.-W.; Meng, Q.; Zhao, L.; Li, J.-J.; Wei, Z.; Han, B.-H. Biomass-derived flexible porous carbon materials and their applications in supercapacitor and gas adsorption. Mater. Des. 2017, 129, 164-172. [CrossRef]

20. Xi, Y.; Wang, Y.; Yang, D.; Zhang, Z.; Liu, W.; Li, Q.; Qiu, X. $\mathrm{K}_{2} \mathrm{CO}_{3}$ activation enhancing the graphitization of porous lignin carbon derived from enzymatic hydrolysis lignin for high performance lithium-ion storage. J. Alloy. Compd. 2019, 785, 706-714. [CrossRef]

21. Han, J.; Kwon, J.H.; Lee, J.-W.; Lee, J.H.; Roh, K.C. An effective approach to preparing partially graphitic activated carbon derived from structurally separated pitch pine biomass. Carbon 2017, 118, 431-437. [CrossRef]

22. Hou, L.; Hu, Z.; Wang, X.; Qiang, L.; Zhou, Y.; Lv, L.; Li, S. Hierarchically porous and heteroatom self-doped graphitic biomass carbon for supercapacitors. J. Colloid Interface Sci. 2019, 540, 88-96. [CrossRef]

23. Paun, V.A.; Popa, M.; Desbrieres, J.; Dragan, S.V.; Zegan, G.; Cioca, G. Liposome loaded chitosan hydrogels, a promising way to reduce the burst effect in drug release a comparativ analysis. Mater. Plast. 2016, 53, 590-593.

24. Xia, J.; Zhang, N.; Chong, S.; Li, D.; Chen, Y.; Sun, C. Three-dimensional porous graphene-like sheets synthesized from biocarbon via low-temperature graphitization for a supercapacitor. Green Chem. 2017, 20, 694-700. [CrossRef]

25. Thompson, E.G.; Danks, A.E.; Bourgeois, L.; Schnepp, Z. Iron-catalyzed graphitization of biomass. Green Chem. 2014, 17, 551-556. [CrossRef]

26. Yahayu, M.; Abas, F.Z.; Zulkifli, S.E.; Ani, F.N. Utilization of oil palm fiber and palm kernel shell in various applications. In Sustainable Technologies for the Management of Agricultural Wastes; Springer: Singapore, 2018; pp. 45-56.

27. Zhang, C.; Lu, G.; Sun, Z.; Yu, J. Catalytic graphitization of carbon/carbon composites by lanthanum oxide. J. Rare Earths 2012, 30, 128-132. [CrossRef]

28. Jiang, F.; Yao, Y.; Natarajan, B.; Yang, C.; Gao, T.; Xie, H.; Wang, Y.; Xu, L.; Chen, Y.; Gilman, J.; et al. Ultrahigh-temperature conversion of biomass to highly conductive graphitic carbon. Carbon 2019, 144, 241-248. [CrossRef] 
29. Kalyoncu, R.S. Graphite. U.S. Geol. Surv. Miner. Yearb. Met. Miner. 2000, 1, 1076.

30. Kim, T.; Lee, J.; Lee, K.-H. Full graphitization of amorphous carbon by microwave heating. RSC Adv. 2016, 6, $24667-24674$. [CrossRef]

31. Um, J.H.; Ahn, C.-Y.; Kim, J.; Jeong, M.; Sung, Y.-E.; Cho, Y.-H.; Kim, S.-S.; Yoon, W.-S. From grass to battery anode: Agricultural biomass hemp-derived carbon for lithium storage. RSC Adv. 2018, 8, 32231-32240. [CrossRef]

32. Shi, J.; Wang, Y.; Du, W.; Hou, Z. Synthesis of graphene encapsulated Fe3C in carbon nanotubes from biomass and its catalysis application. Carbon 2016, 99, 330-337. [CrossRef]

33. Thambiliyagodage, C.; Ulrich, S.; Araujo, P.; Bakker, M.G. Catalytic graphitization in nanocast carbon monoliths by iron, cobalt and nickel nanoparticles. Carbon 2018, 134, 452-463. [CrossRef]

34. Qin, H. Catalytic Graphitization Strategy for the Synthesis of Graphitic Carbon Nanocages and Electrochemical Performance. Int. J. Electrochem. Sci. 2017, 12, 10599-10604. [CrossRef]

35. Käärik, M.; Arulepp, M.; Karelson, M.; Leis, J. The effect of graphitization catalyst on the structure and porosity of SiC derived carbons. Carbon 2008, 46, 1579-1587. [CrossRef]

36. Shi, W.; Chang, B.; Yin, H.; Zhang, S.; Yang, B.; Dong, X. Crab shell-derived honeycomb-like graphitized hierarchically porous carbons for satisfactory rate performance of all-solid-state supercapacitors. Sustain. Energy Fuels 2019, 3, 1201-1214. [CrossRef]

37. Gutiérrez-Pardo, A.; Ramírez-Rico, J.; Cabezas-Rodríguez, R.; Martínez-Fernández, J. Effect of catalytic graphitization on the electrochemical behavior of wood derived carbons for use in supercapacitors. J. Power Sources 2015, 278, 18-26. [CrossRef]

38. Khokhlova, G.P.; Barnakov, C.N.; Malysheva, V.Y.; Popova, A.N.; Ismagilov, Z.R. Effect of heat treatment conditions on the catalytic graphitization of coal-tar pitch. Solid Fuel Chem. 2015, 49, 66-72. [CrossRef]

39. McKee, D.W. Carbon and Graphite Science. Annu. Rev. Mater. Res. 1973, 3, 195-231. [CrossRef]

40. Liu, Y.; Liu, Q.; Gu, J.; Kang, D.; Zhou, F.; Zhang, W.; Wu, Y.; Zhang, D. Highly porous graphitic materials prepared by catalytic graphitization. Carbon 2013, 64, 132-140. [CrossRef]

41. Sevilla, M.; Fuertes, A. Graphitic carbon nanostructures from cellulose. Chem. Phys. Lett. 2010, 490, 63-68. [CrossRef]

42. Nettelroth, D.; Schwarz, H.-C.; Burblies, N.; Guschanski, N.; Behrens, P. Catalytic graphitization of ordered mesoporous carbon CMK-3 with iron oxide catalysts: Evaluation of different synthesis pathways. Phys. Status Solidi 2016, 213, 1395-1402. [CrossRef]

43. Hoekstra, J.; Beale, A.; Soulimani, F.; Versluijs-Helder, M.; Geus, J.W.; Jenneskens, L.W. Base Metal Catalyzed Graphitization of Cellulose: A Combined Raman Spectroscopy, Temperature-Dependent X-ray Diffraction and High-Resolution Transmission Electron Microscopy Study. J. Phys. Chem. C 2015, 119, 10653-10661. [CrossRef]

44. Hoekstra, J.; Beale, A.; Soulimani, F.; Versluijs-Helder, M.; van de Kleut, D.; Koelewijn, J.M.; Geus, J.W.; Jenneskens, L.W. The effect of iron catalyzed graphitization on the textural properties of carbonized cellulose: Magnetically separable graphitic carbon bodies for catalysis and remediation. Carbon 2016, 107, 248-260. [CrossRef]

45. Yan, Q.; Li, J.; Zhang, X.; Hassan, E.B.; Wang, C.; Zhang, J.; Cai, Z. Catalytic graphitization of kraft lignin to graphene-based structures with four different transitional metals. J. Nanoparticle Res. 2018, 20, 223. [CrossRef]

46. Rashidi, N.A.; Yusup, S. Co-valorization of delayed petroleum coke-palm kernel shell for activated carbon production. J. Hazard. Mater. 2021, 403, 123876. [CrossRef]

47. Chin, C.O.; Yang, X.; Paul, S.C.; Susilawati; Wong, L.S.; Kong, S.Y. Development of thermal energy storage lightweight concrete using paraffin-oil palm kernel shell-activated carbon composite. J. Clean. Prod. 2020, 261, 121227. [CrossRef]

48. Yang, X.; Li, F.; Xia, M.; Luo, F.; Jiang, Y. Investigation on the micro-structure and adsorption capacity of cellulosic biomass carbon based montmorillonite composite. Microporous Mesoporous Mater. 2018, 256, 18-24. [CrossRef]

49. Pudukudy, M.; Yaakob, Z.; Takriff, M.S. Methane decomposition over unsupported mesoporous nickel ferrites: Effect of reaction temperature on the catalytic activity and properties of the produced nanocarbon. RSC Adv. 2016, 6, 68081-68091. [CrossRef]

50. Sevilla, M.; Sanchís, C.; Solis, M.S.; Morallón, E.; Fuertes, A.B. Synthesis of Graphitic Carbon Nanostructures from Sawdust and Their Application as Electrocatalyst Supports. J. Phys. Chem. C 2007, 111, 9749-9756. [CrossRef]

51. Sevilla, M.; Lecea, C.S.M.-D.; Solis, M.S.; Morallón, E.; Fuertes, A.B. Solid-phase synthesis of graphitic carbon nanostructures from iron and cobalt gluconates and their utilization as electrocatalyst supports. Phys. Chem. Chem. Phys. 2008, 10, 1433-1442 [CrossRef] [PubMed]

52. Johnson, M.; Faber, K. Catalytic graphitization of three-dimensional wood-derived porous scaffolds. J. Mater. Res. 2011, 26, 18-25. [CrossRef]

53. Liu, W.-J.; Tian, K.; He, Y.-R.; Jiang, H.; Yu, H.-Q. High-Yield Harvest of Nanofibers/Mesoporous Carbon Composite by Pyrolysis of Waste Biomass and Its Application for High Durability Electrochemical Energy Storage. Environ. Sci. Technol. 2014, 48, 13951-13959. [CrossRef]

54. Zhao, J.; Liu, Y.; Quan, X.; Chen, S.; Yu, H.; Zhao, H. Nitrogen-doped carbon with a high degree of graphitization derived from biomass as high-performance electrocatalyst for oxygen reduction reaction. Appl. Surf. Sci. 2017, 396, 986-993. [CrossRef]

55. Yang, J.; Zuo, S. Facile synthesis of graphitic mesoporous carbon materials from sucrose. Diam. Relat. Mater. 2019, 95, 1-4. [CrossRef]

56. Qiu, T.; Yang, J.-G.; Bai, X.-J.; Wang, Y.-L. The preparation of synthetic graphite materials with hierarchical pores from lignite by one-step impregnation and their characterization as dye absorbents. RSC Adv. 2019, 9, 12737-12746. [CrossRef]

57. Vázquez-Santos, M.B.; Geissler, E.; László, K.; Rouzaud, J.-N.; Martínez-Alonso, A.; Tascon, J.M.D. Comparative XRD, Raman, and TEM Study on Graphitization of PBO-Derived Carbon Fibers. J. Phys. Chem. C 2012, 116, 257-268. [CrossRef] 
58. Zhou, X.; Chen, F.; Bai, T.; Long, B.; Liao, Q.; Ren, Y.; Yang, J. Interconnected highly graphitic carbon nanosheets derived from wheat stalk as high performance anode materials for lithium ion batteries. Green Chem. 2016, 18, 2078-2088. [CrossRef]

59. Chen, C.; Sun, K.; Wang, A.; Wang, S.; Jiang, J. Catalytic Graphitization of Cellulose Using Nickel as Catalyst. BioResources 2018, 13, 3165-3176. [CrossRef]

60. Lim, Y.; Chu, J.H.; Lee, D.H.; Kwon, S.-Y.; Shin, H. Increase in graphitization and electrical conductivity of glassy carbon nanowires by rapid thermal annealing. J. Alloy. Compd. 2017, 702, 465-471. [CrossRef]

61. Major, I.; Pin, J.-M.; Behazin, E.; Rodriguez-Uribe, A.; Misra, M.; Mohanty, A. Graphitization of Miscanthus grass biocarbon enhanced by in situ generated FeCo nanoparticles. Green Chem. 2018, 20, 2269-2278. [CrossRef]

62. Zhang, P. Adsorption and Desorption Isotherms. 2016. Available online: http://www.keresearchgroup.com/uploads/4/8/4/5/ 48456521/160903_introduction_to_bet_isotherms.pdf (accessed on 15 February 2021).

63. Wu, F.; Huang, R.; Mu, D.; Wu, B.; Chen, Y. Controlled synthesis of graphitic carbon-encapsulated $\alpha-\mathrm{Fe}_{2} \mathrm{O}_{3}$ nanocomposite via low-temperature catalytic graphitization of biomass and its lithium storage property. Electrochim. Acta 2016, 187, 508-516. [CrossRef]

64. Liu, Y.; Nie, Y.; Lu, X.; Zhang, X.; He, H.; Pan, F.; Zhou, L.; Liu, X.; Ji, X.; Zhang, S. Cascade utilization of lignocellulosic biomass to high-value products. Green Chem. 2019, 21, 3499-3535. [CrossRef]

65. Yuliansyah, A.T.; Hirajima, T. Efficacy of hydrothermal treatment for production of solid fuel from oil palm wastes. Resour. Manag. Sustain. Agric. 2012. [CrossRef]

66. Liu, D.; Zhao, X.; Su, R.; Hao, Z.; Jia, B.; Li, S.; Dong, L. Highly porous graphitic activated carbons from lignite via microwave pretreatment and iron-catalyzed graphitization at low-temperature for supercapacitor electrode materials. Process. 2019, 7, 300 . [CrossRef]

67. Yu, Z.-L.; Xin, S.; You, Y.; Yu, L.; Lin, Y.; Xu, D.-W.; Qiao, C.; Huang, Z.-H.; Yang, N.; Yu, S.-H.; et al. Ion-catalyzed synthesis of microporous hard carbon embedded with expanded nanographite for enhanced lithium/sodium storage. J. Am. Chem. Soc. 2016, 138, 14915-14922. [CrossRef] [PubMed]

68. Kamal, A.S.; Othman, R.; Jabarullah, N.H. Preparation and synthesis of synthetic graphite from biomass waste: A review. Syst. Rev. Pharm. 2020, 11, 881-894. 